their spectra observed. Moreover, by the use of the iris diaphragm, which is placed below the substage condenser, the marginal part of the field can be readily cut off. Another piece of apparatus is indispensable, namely, the compressorium, as by its aid the section is squeezed out thin enough to allow the spectrum to be observed.

No reagent whatever is required for the detection of the spectra to be described, so that the substances present cannot be altered in any way.

Myohemalin.-Physiologists have accepted Kuihne's statement that muscle owes its colour to hæmoglolin, but although the majority of voluntary muscles do owe their colour to it, it is accompanied by myohæmatin in most cases, and sometimes entirely replaced by it, while in other cases it entirely replaces myohæmatin. The heart muscle of every vertebrate animal which I have examined yiclds myohæmatin, which gives a very beautifully defined spectrum totally distinct from any decomposition product of hæmoglobin, e.g. methæmoglobin, acid or alkaline hamatin, or hamatoporphyrin. All one has to do in order to detect myohrmatin is to cut off a bit of heart muscle, put it while fresh in the compressorium, press it down, and observe the spectrum. No reagent whatever is required. The spectrum consists of three bands, two of which are very narrow, and persist after the hæmoglobin bands have gone when the tissue has been squeezed out to great thinness in the compressorium. The bands have been missed by other observers simply because when the oxyhæmoglobin bands are well marked they cover and are merged into the myohæmatin bands. The first band of myohæmatin occurs just before D, the next two (of great narrowness) are placed between $\mathrm{D}$ and $\mathrm{E}$, and two other faint bands may be present nearer violet, of which the first covers $\mathrm{F}$ and $b$, and the other is between $b$ and $\mathrm{F}$, close to latter line. Their wave-lengths are : Ist band $\lambda 613-596 \cdot 5$, and band $\lambda 569$ 563 , 3rd band $\lambda 556-549$ (heart of $\operatorname{dog}$ ), and they have been measured in all cases with the same result. I find myohæmatin in the heart muscles and some voluntary muscles of the following

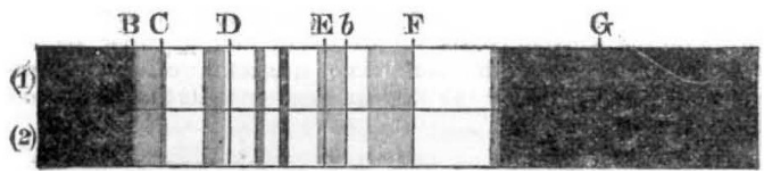

r.-Myohæmatics from $\Lambda$ lar muscles of Vespa vulgaris. 2.-Myohxmatics from heart of Lim $x x$ zariegiatus.

mammals:-Man, dog, cat, rabbit, guinea-pig, hedgehog, sheep, ox, pig, rat and hare. In birds . in pigcon, owl, duck, goose, turkey, and fowl. In reptiles : in green lizard, common ringed snake, and fresh-water tortoise. In Batrachians: in toad, frog, salamander, axolotl, and tree-frog. In fishes: in herring, mackerel, tench, roach, eel, plaice, whiting, and corlfish. ${ }^{1}$ But it is also found in Invertebrates, in which I first detectcd it. It is found in the muscle from thorax and in leg muscles of the following insect genera :-Dytiscus, Hydrophilus, Lucanus, Cerambyx, Creophilus, Staphylinus, Geotrupes, Carabus, Coccinella, Musca (three species), 'lipula, Gryllus, Blatta, Vespa, Apis, Bombus, Pieris, Ennomos, \&c. It also occurs in the cephalo-tbracic muscles of spiders, in the heart of the crab, lobster, and crayfish (and not in their voluntary muscles) ; in the heart and buccal muscles of Arion, Limax, Helix, and other pulmonatc mollusks, while in other mollusks it appears to be replaced by hamoglobin in the pharyngeal muscle, as Prof. Lankester has found out

Two attempts have been made to isolate it. In the first it was got out of the muscle by digesting in pepsine solution, and was slightly changed in the process; in the second it was got out of the frozen heart muscle of a rabbit by pressing out the plasma;" here it was mixed with traces of hæmoglobin, but could be differentiated from it: hence it probably occurs in muscle plasma like muscle-hæmoglobin.

Histohamatin. - This name has been given by me to a cla $\mathrm{s}$ of pigments or modifications of the same pigment, which are found widely distributcd in the animal kingdom. Myohæmatin belongs to them, as can easily be shown. They are found in Mollusks, Arthropods, Echinoderms, and, modified peculiarly, in Cœlenterates. The bands are carefully measured and compared

I These being all the vertebrate animals which I have yet examined.

2 After suitable precautions had been taken to cxclude the influence of the blood, as fully described in the demonstration. with spectra yielded by various organs and tissues of Vertebrates, and no difference is found between those of Vertebrates and Invertebrates. In order to see these spectra in the higher animals the blood-vesscls are washed out with salt solution thoroughly, and then the organs and tissues examined in the manner de scribed. It is not possible to go into this subject in an abstract, as the facts are too numerous to be compressed into such a small space ; it will suffice to say that the histohæmatins are respiratory pigments, as can be proved by oxidising and reducing them in the solid organs. Their bands occupy almost the same place as those of myohrematin, except that the second and third bands of the myohrematin spectrum appear compressed into one in some cases.

Myohæmatin itself is also undoubtcdly a respiratory substance.

Spectrum of the Supra-renal Bodies. - In the supra-renals of man, cat, dog, guinea-pig, rabbit, ox, sheep, pig, and rat, the medulla gives the spectrum of hæmochromogen, while the cortex shows that of a histohæmatin. Wherever we find hæmochromogen in a vertebrate body it is probably excretory, and I have only found it in the bile and in the liver. Hence, and owing to the remarkable darkness of its bands in the medulla of the adrenals, it must be looked upon here as excretory; if so, the function of the adrenals must be (at least in part) to metamorphose effete hæmoglobin or hæmatin into hæmochromogen; if from disease, or after removal, as in Tizzoni's experiments, the effete pigment is not removed, pigmentation of skin and mucous membiane may take place. The presence of taurocholic acid in the medulla (Vulpian), the resemblance in the structure of the adrenals to that of the liver, and the large lymphatics, with the well-known results of discase of the adrenals in Addison's disease, all go to show that an active metabolic process is taking place in them, and I believe I am justified in concluding that they have a large share in the downward metamorphosis of effete culouring matter, and that these observations will help to throw some light on $\Lambda$ ddison's discase.

\section{SOUTH GEORGIA}

OME interesting particulars of the gcography, climate, \&c., of the island of South Georgia have recently becn published by the members of the German Expedition which sojourned in I88 3 at the island. They are of the more interest as no scientific expedition had previously visited the island, of which but little therefore is known. The Expedition, in command of Dr. Schrader, took up their quarters at Moltke IIafen, in Royal Bay, which is from four and a half to five miles wide and from six to eight miles long; here observations were made from September 15, 1882, until September 3, 1883 , when the Expedition left in a German gunboat. The 8472 obscrvations made during this period on the temperature, air-pressure, moisture, wind, $\delta c$., are of great importance.

The island is by its position $\left(54^{\circ} 3 \mathrm{r}^{\prime} \mathrm{S}\right.$. lat. and $36^{\circ} 5^{\prime} \mathrm{W}$. long.) not an Antarctic island in the strict sense of the word, but its appcarance stamps it as such-Royal Bay bcing surrounded by mountains, with enormous glaciers from 900 to $\mathrm{r} 200$ feet in height, which further inland rise to 6000 or 7000 feet. This circumstance may give some idea of the climate, and it is therefore not surprising to learn that the mean temperature of the whole period of observation was only $35^{\circ} \mathrm{F}$. ; for February, the warmest month, $42^{\circ}$, and for the coldest (June) $26^{\circ} \cdot 6$. No single month was free from frost, and 30 per cent. of the hours of observation showed a temperature below freezing-point. In July the minimum-thermometer registered $26^{\circ} \cdot 2$, and in February the maximum-thermometer $57^{\circ} \cdot 2$, the range of temperature amounting to $3 x^{\circ}$. Clear days occurred in the winter only, the total number bcing 8 ; whereas the total of cloudy days was 127; the Latter were Iess frequent in July and August. During December not a single day was clcar, and the total number of hours of clear sky was only 269 , against 3302 which were cloudy, viz. 38.9 per cent. of the total, Consequently there was much rain and snow, particularly in November and December, which had only one dry day each. Most snow fell in March and lcast in May. Even the warmest month, February, had 13 days with snow, while the coldest, June, had four days with rain. It hailed on 19 days, principally in December; there were 75 days of fog, but it did not last long. As regards winds and storms, the observations of the Expedition seem to indicate that the neighbourhood of Cape Horn is not quite so stormy as is generally believed. At South Georgia there were 
many days of perfect calm; the summer was, however, more stormy than the winter. The winds came chiefly from the west-those from a dic westerly direction being most common -and also from wcst-south-wcst or north-west. The westerly and south-westerly winls were during the winter the warmest, which is ascribed to the circumstance that they passed over mountains some 6000 feet in height, which rendered them "Föhn-like." The barometer readings were never attended by violent storms; these occurred without exception when the glass stood at "fair." 'There was no aurora australis, nor were there any thunderstorms.

Explorations of the island were undertaken on several occasions, and many of the peaks in the neighbourhood of Royal Hay were climbed. The slate rocks were very difficult of ascent. The enormous glacicrs in the mountains of the interior prevented, unfortunately, any thorough exploration of this part. The mountains often sloped alruply int, the sea, and the highest points were about ten milcs from the station and covered with eternal snow. The roar of avalanches was continually heard. The fauna was very poor. That such a clreary climate should boast of a very extensive fauna or flora was hardly to be expected ; nevertheless, the mosses were very fine. Dr. H. Will, the botanist, collected about thirty varieties. They show what a climate where the sun is nearly always absent can produce in the way of plants which arc able to resist rapid changes of temperaturc, but the fauna is one which may at once be said to belong to more Antarctic regions than Terra del Fuego, the Kerguelen Islands, and more northerly places. It is a repetition of the same types, with originality in,details alonc.

\section{CARTOGRAPHICAL WORK IN RUSSIA}

WE learn from a recent issue of the I3vestir of the Russian Geographical Society that the following geodetical and cartographical work was done during the year I 883 by the officers of the Russian General Staff. The first-class triangulation for connecting the line of Warsaw and Grodno with that of the Vistula was continued; the secondary network of triangulation was extended in Lithuania and Poland; and the heights of 262 places were determined by careful levellings. The most useful work of exact levellings on the Russian railways, undertaken several years since, was continuted in West and South-West Russia, leading to a precise measurement of the differences of level between the Baltic and the Black Seas, and the final results are now being calculated. The Russian survey was continued on the scales of 1400 and 1750 feet to an inch, in Poland, Lithuania, Bessarabia, and Finland ; and a most welcome feature of it is that great attention was given to the measurements of heights, so that a map with level-lines only, 35 to 70 feet apart from one another, may be published. In the Caucasus very accurate measurements of the latitudes and longitudes of Tiflis, Baku, and Shemakla were made, as also pendulum observations in Trans-Caucasia. Of trigonometrical mcasurements, the triangulation of the Trans-Caspian region was continued as far as the Persian frontier, and that of Akhal-Tekke, was also calculated. An interesting feature of this last was the measurcment of two geodetical bases on strings which methnd gives, as is known, very satisfactory results - together with a inuch greater economy of time. Detailcd surveys were continued in several parts of the Caucasus, those at Askabad, and between Kyzil-Arvat, Bami, and the Sumbar River (two versts to an inch) being especially worthy of notice.

In Turkestan, at the 'Tashkend Observatory, Col. Pomcrantseff continued his observations of minor planets with the refractor of the Observatory, and the mcasurement of stars by means of the meridian-circle; and his assistant, Capt. Zalcssky, regularly made measurements of occultations of stars by the moon. The work of the Observatory will soon he publisher, and will contain an elaboralc paper by Dr. Schwartz, on magnetism in Turkestan. Several most valuable determinations of latimies and longitude werc made by M. Putyata in the Pamir during M. Ivanoff's expedition. Among many surveys which were made this year, that of the northern slope of the Turkestan ridge was especially interesting, no less than twenty-three unknown glaciers having been discovered at the sources of the Sokh, and mapped. The Shemanovsky glacier, eight miles long, and that of Ak-terek, twenty-two miles long, which joins the well-known Zarafshan glacier, are especially worthy of notice. A survey of the rich oasis of Karshi, and of the Bokhara dominions on the right bank of the Zarafshan, is also very interesting. The map of Turkestan on the scalc of ten versts (seven miles) to an inch, is already in print, and several sheets are nearly ready.

In the Omsk military district we notice several determinations of latitudes and longitudes, as also the survey of the Kirghiz Steppe, on a scaite of five versts to an inch. In Eastern Siberia the chief work was the further extension of the triangulation of Trans-Baikalia-a most necessary work, on accoint of the scarcity of determined points to fix the surveys in that regionand many local surveys, those in the Ussuri region and on the Pacific coast bcing. especially interesting. The astronomically determined points, very few on the whole, have received only seven additions.

The Hydrographical Department has pursued its work on the Baltic, the Black, and the Caspian Seas, as also on some lakes in the interior of Russia and Finland ; the most interesting of them being several detailcd maps of the Lake of Onega, and the Lakes Päyänne and Pielis, in Finland ; the triangulation and surveys on the Caucasian coast of the Black Sea; and the survey of the Gulf Mortvyi Kultuk of the Caspian.

Among the publications of the General Staff we notice the thirty-ninth volume of its Mencirs, which contains the following papers :-On the triangulation of liessarabia, by Col. Lebedeff; on the difference between the longitudes of Tashkend and Vernyi, by $\mathrm{Col}$. Pomerantseff; on astronomical determinations made in Trans-Baikalia (fifty-two placcs), by Capt. Polanovsky ; in the Altay region and in West Siberia (thirtcen places), by Col. Miroshnitchenko; in the Trans-Caspian region (with a map), by Col. Gladysheff; and in North-West Mongolia, by Lieut. Rafailoff; on levellings on Russian railways ; on the determination of time by means of the meridian-circle, by M. Gladysheff; on the Trans-Caspian triangulation (ninety-two places), by Capt. Pervas, in which it is stated that Askabad is 827 feet, and Mount Riza, on the Persian frontier, 974I feet, above the sealevel ; and finally, a description by Col. Alexandroff of the route from Kungrad to the Gulf of Mortvyi Kultuk, the distance heing 300 miles, of which about 90 miles are without water.

The Annual Report of the Hydrographical Department contains seven small maps showing the exact results of the surveys made on the Russian coasts up to 1882 ; and a paper by $M$. Goloviznin gives at the same timc a sketch of the hydrographical work done by the Rusvian flect since its first formation in 1696 .

\section{SCIENTIFIC SERIALS}

In the Fournal of Botany for January Mr, H. N, Ridley describes and figures the extremely rare foncus tenuis, a plant entirely lust to Britain since 1795 or 1796 , when it was gathered by G. Don in Clova, till $188_{3}$, when it was rediscovered by $\mathrm{Mr}$. Towndrow in Herefordshire. Mr. W. H. Beeby records another interesting addition to the British flora in a new Sparganium, which he names $S$. neglectum, nearly allied to $S$. ramosum, and probably a sub-species of it, found in ponds in several parts of surrey.

THE last part of the Belgiquz? Horticole that has reached us, that for May and June 1884 , contains but little that is original, the substantial articles being taken from French, German, or English journals. The coloured plates of new or little-known plants, with accompanying descriptions, are of their usual excellence, and there are many short paragraphs of interest to horticulturists.

\section{SOCIETIES A.VD ACADEMIES LONDON}

Royal Society, January $29 .-$ "On some Physical Properties of Ice and on the Motion of Glaciers, with special reference to the late Canon Moseley's Objections to Gravitation Theorics." By Coutts Trotter, M.A., Fellow of Trinity Collegc, Cambridge. Communicated by Prof. Stokes, Ser. R.S.

Canon Moseley's theory of glacier motion, pul forward in 1855, has never been accepted by persons conversant with glaciers. In 1869, however, he pht forward a somewhat formidable objection to the current gravitation theories of glacier motion.

The gist of the objection is that the resistance of icc to shearing is many times greater than the shearing force which can be produced in a descending glacier by gravity; and that thcrefore the shearing which the measurements of Forbes and 